BIOMEDICAL AND BIOSOCIAL ANTHROPOLOGY
$\begin{gathered}\text { Official Journal of the International Academy } \\ \text { of Integrative Anthropology } \\ \text { journal homepage: http://bba-journal.com }\end{gathered}$

\title{
Effect of TXNRD2 rs35934224, FOXC1 rs2745599 and rs984253 genetic polymorphisms combinations on the development of primary open-angle glaucoma and their degree of association with the disease
}

Malachkova N. V., Veretelnyk S. P., Slobodian P. P.

National Pirogov Memorial Medical University, Vinnytsya, Ukraine

\author{
ARTICLE INFO \\ Received: 4 September, 2018 \\ Accepted: 30 October, 2018
}

UDC: $617.7-007.681: 575.113$

\section{CORRESPONDING AUTHOR}

e-mail: malachkovanataliia@gmail.com Malachkova N. V.
Primary open-angle glaucoma (POAG) is a complex disease caused by numerous genetic and environmental factors, as well as their interaction. In recent studies, the effect of genetic polymorphisms combinations and non-equilibrium linkage of allele genes related to the development of POAG has been proved. The aim of the study was to determine the effect of TXNRD2 rs35934224, FOXC1 rs2745599 and rs984253 genetic polymorphisms combinations on the development of primary open-angle glaucoma and their degree of association with the disease. The study included 93 patients (185 eyes) with POAG stage I-IV and 89 volunteers (178 eyes) control subjects without any types of glaucoma. The patients were divided into four groups according to the degree of perimetric changes (Nesterov A. P., 2008). All patients performed visometry, computer perimetry, tonometry, biomicroscopy, ophthalmoscopy, gonioscopy, keratopahymetry, optical coherent tomography of the optic nerve. Analysis of the TXNRD2 rs35934224, FOXC1 rs2745599 and rs984253 genetic polymorphism with POAG was performed in real time using a polymerase chain reaction (PCR) in Gene Amp® PCR System 7500 (Applied Biosystems, USA) automatic amplifier. In the first stage of the study, the genomic DNA from whole venous blood was isolated using the standard reagents PureLink $\Theta$ Genomic DNA Kit for purification of genomic DNA, manufactured by INVITROGEN (USA). The analysis of polymorphism was carried out using unified test systems of TaqMan Mutation Detection Assays Life-Technology (USA). It was determined that the association with POAG had the genotype $C / T^{\star} A / A^{\star} T / A$ as by comparing control with all patients, and by stratification with the 1st, 2nd and 3rd groups of patients. The obtained results showed the evidentiary effect of this genotype combinations on the appearance of POAG, and on its progression by the stages of perimetric changes. The risk of the occurrence of POAG in carriers of genotypes $C / T^{\star} A / A^{\star} T / A$ was increased by 2.8 times $(p<0.001)$. In this combination, the two polymorphisms had heterozygous genotypes (rs35934224 - C/T, rs984253 - T/A), and the genotype rs2745599 - a mutant homozygote $A / A$. A combination of genotypes $C /$ $C^{*} G / A^{*} T / A$ was also important for the progression of the disease till stage II, which increased the risk of development of the POAG stage II by 2.9 times $(p<0.01)$ compared to control. The risk of occurrence of the POAG in general and development of stage IV increased the presence of combinations of three minor genotypes $T / T^{*} A / A^{*} A / A$, which was encountered only in patients with POAG (in stage $I I-f=0.025$, in the third stage $-f=$ 0.036 , and in $I V-f=0.071$ ). In our opinion, it confirmed the proposed working hypothesis of the study and showed that the more genotype combinations have the mutant alleles, the stronger this genotype affects the development of POAG.

Keywords: primary open-angle glaucoma, chromosome, genotype, polymorphism, TXNRD2 gene, FOXC1 gene, allele, heterozygote.

\section{Introduction}

Primary open-angle glaucoma (POAG) is a complex disease caused by the combined effects of many genetic and environmental risk factors, each of which do not act alone to cause glaucoma. Recent advances in molecular 
genetics have shown that POAG can be caused by numerous gene mutations in various chromosomal loci. $A$ study performed by Cong $G$. et al. estimated that inherited and familial POAG cases may account for approximately $72 \%$ of all POAG cases [6, 7, 8, 22, 27].

Another gene for testing as the genetic marker of the primary open-angle glaucoma (POAG) has become the developmental gene: forkhead box C1 (FOXC1) [1, 28]. This gene plays an important role in the normal morphogenesis of the anterior segment of the eye and is involved in the regulation of intraocular pressure and the function of the trabecular mesh [21]. The FOXC1 gene (previously FKHL7) is one of the six known genes of glaucoma [28]. Although FOXC1 expression has not been studied in adults yet, it is possible that prolonging the expression of an abnormal gene product (from age-related, sub-clinical mutations) throughout life, or altering the expression level of FOXC1 may affect the normal function of the trabecular mesh, thereby leading to an increased risk for the development of POAG through difficulty in drainage and increased intraocular pressure [26].

Another gene that has attracted our attention is the TXNRD2 gene encoding the mitochondrial protein, thioredoxin reductase 2 , which is required for mitochondrial redox homeostasis. Thioredoxin 2 reduces the damaging effect of active forms of oxygen, which are formed as a result of oxidative phosphorylation [4]. And the decrease in the number of active forms of oxygen by activating the expression of the TXNRD2 gene prevents mitochondrial dysfunction and apoptosis of ganglion cells in POAG [1, 2].

In recent proceedings devoted to genetic research in the POAG [1, 21], the effects of combinations of polymorphic genotypes and non-equilibrium linkage of allele genes related to the development of POAG were considered. This approach is a very promising area of research, since a particular patient has a certain common genotype consisting of the specific polymorphic genotypes combinations.

That is why, in our opinion, when conducting studies of several polymorphic genes it is advisable to consider the association of genotype combinations with the development of the disease.

The aim of the study was to determine the effect of TXNRD2 rs35934224, FOXC1 rs2745599 and rs984253 genetic polymorphisms combinations on the development of primary open-angle glaucoma and their degree of association with the disease.

\section{Materials and methods}

The research was performed at the Department of Eye Diseases of the National Pirogov Memorial Medical University and the department of ophthalmology of Vinnitsa Regional Clinical Hospital Named After N. I. Pirogov. The examination of patients and the diagnosis of POAG was carried out in accordance with the classification of $A$. $P$. Nesterov perimetric changes in the stages of glaucoma [17].

The study included 93 patients (185 eyes) with POAG stage I-IV and 89 volunteers (178 eyes) control subjects without any types of glaucoma. The patients were divided into four groups according to the degree of perimetric changes [17]. All patients performed visometry, computer perimetry, tonometry, biomicroscopy, ophthalmoscopy, gonioscopy, keratopahymetry, optical coherent tomography of the optic nerve.

All stages of molecular genetic research were carried out at the Research Institute of Experimental and Clinical Medicine of the O. O. Bogomolets National Medical University (chief - m.d., professor Natrus L.V.). Analysis of the TXNRD2 rs35934224, FOXC1 rs2745599 and rs984253 genetic polymorphism with POAG was performed in real time using a polymerase chain reaction (PCR) in Gene Amp® PCR System 7500 (Applied Biosystems, USA) automatic amplifier. In the first stage of the study, the genomic DNA from whole venous blood was isolated using the standard reagents PureLink ${ }^{\circledR}$ Genomic DNA Kit for purification of genomic DNA, manufactured by INVITROGEN (USA). The analysis of polymorphism was carried out using unified test systems of TaqMan Mutation Detection Assays Life-Technology (USA). For statistical analysis of the results, MedStat and MedCalc v.15.1 (MedCalc Software bvba) were used. Association of genotypes and alleles with the disease were determined by the odds ratio $(\mathrm{OR})$; The limits of $95 \%$ of the credible interval (CI) were calculated by the method of J. Neyman. The differences were statistically significant at $p<0.05$. To test the probability of differences between groups, $X^{2}$ was used and Fischer's exact criterion was used.

\section{Results}

The association with the disease has been confirmed only for genotype combinations $C / C^{*} A / A^{*} T / A$. It was shown that this genotype was found in the control group with a frequency of $f=0.101$, and with $P O A G$ - with frequency $f=$ 0.238 , that is, 2.4 times more often $(p<0.001)$.

The genotype combinations $C / C{ }^{\star} A / A^{\star} T / A$ increased the chances of development of the POAG compared to the control by 2.8 times $(\mathrm{OR}=2.775 ; 95 \% \mathrm{Cl}=1.532-5.021)$. Also, the genotype combinations of $T / T^{*} A / A^{*} A / A$ increased the risk of development POAG $(p<0.05)$, since such genotype wasn't detected in the control group. It should be noted that this genotype is a combination of all three mutant homozygotes. This fact confirmed the negative effect of the mutant alleles of all three polymorphisms on the occurrence of POAG.

According to the Table 1, four genotype combinations $C$ / $C^{*} \mathrm{~A} / \mathrm{A}^{*} \mathrm{~T} / \mathrm{T}, \mathrm{C} / \mathrm{C}^{*} \mathrm{G} / \mathrm{A}^{*} \mathrm{~T} / \mathrm{T}, \mathrm{C} / \mathrm{C}^{*} \mathrm{G} / \mathrm{G}{ }^{*} \mathrm{~T} / \mathrm{T}$ and $\mathrm{C} / \mathrm{T}{ }^{*} \mathrm{G} / \mathrm{A}^{*} \mathrm{~T} / \mathrm{T}$ showed a strong protective effect on $P O A G$ and substantially reduced the chances of development POAG.

The maximum power of connection was determined to genotype combinations $\mathrm{C} / \mathrm{C}^{*} \mathrm{G} / \mathrm{G}{ }^{*} \mathrm{~T} / \mathrm{T}$, which reduced the chances of development POAG by 7.7 times $(\mathrm{OR}=0.132$; $95 \% \mathrm{Cl}=0.044-0.338)$. The genotype combinations $\mathrm{C} / \mathrm{T}^{*} \mathrm{G} /$ $A^{*} \mathrm{~T} / \mathrm{T}$ reduced the chances by 6.7 times $(\mathrm{OR}=0.157 ; 95 \%$ $\mathrm{Cl}=0.035-0.697)$ and the genotype combinations $C / C^{*} A /$ $A^{*} \mathrm{~T} / \mathrm{T}$ and $\mathrm{C} / \mathrm{C}^{*} \mathrm{G} / \mathrm{A}^{*} \mathrm{~T} / \mathrm{T}-3.8$ times for both cases $(\mathrm{OR}=$ $0.263 ; 95 \% \mathrm{Cl}=0.101-0.685)$. 
Table 1. Influence of genotype combinations on the development of POAG and their degree of association with the disease.

\begin{tabular}{|c|c|c|c|c|c|c|}
\hline Genotypes & POAG & Control & $\chi^{2}$ & $\mathrm{P}$ & OR & $95 \% \mathrm{Cl}$ \\
\hline$C / C^{*} A / A^{\star} T / A$ & 0.242 & 0.103 & 11.03 & $<0.001$ & 2.775 & $1.532-5.021$ \\
\hline$C / C^{\star} A / A^{\star} T / T$ & 0.033 & 0.111 & 7.552 & $<0.01$ & 0.263 & $0.101-0.685$ \\
\hline$C / C^{\star} G / A^{\star} T / T$ & 0.033 & 0.111 & 7.552 & $<0.01$ & 0.263 & $0.101-0.685$ \\
\hline$C / C^{*} G / G^{*} T / T$ & 0.024 & 0.152 & 16.93 & $<0.001$ & 0.132 & $0.044-0.383$ \\
\hline$C / T^{*} G / A^{*} T / T$ & 0.015 & 0.073 & 6.392 & $<0.05$ & 0.157 & $0.035-0.697$ \\
\hline$T / T^{\star} A / A^{*} A / A$ & 0.031 & 0.001 & 4.044 & $<0.05$ & $\max$ & N/A-max \\
\hline
\end{tabular}

Notes: $X^{2}$ - Pearson's $x$-square criterion; $p$ - statistical significance OR - odds ratio; $95 \% \mathrm{Cl}-95 \%$ credible interval for OR.

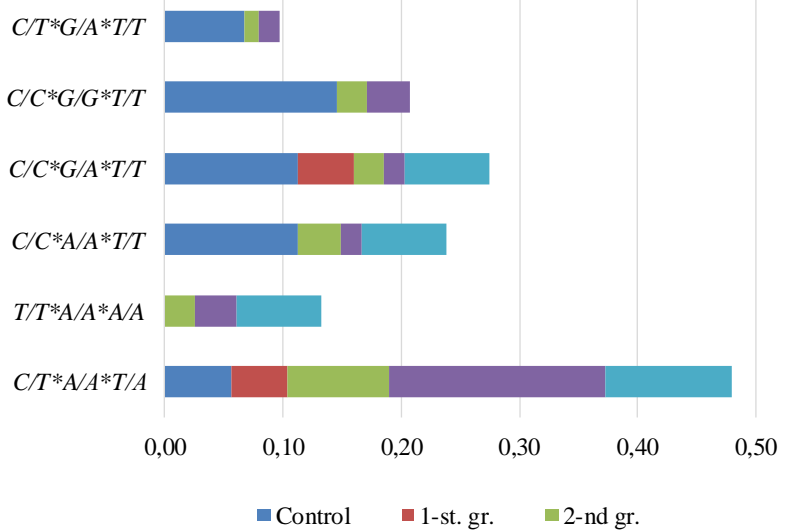

Fig. 1. Distribution of frequencies of genotype combinations in the control group and in patients with POAG when stratified in groups. The diagram shows genotype combinations for which the statistical significance of the differences at level $p<0.05$ in the groups of comparisons was found, as well as the associative relation with the disease $(O R>0)$ according to the tables 1 and 2.

Table 2. Influence of genotype combinations on the development of POAG and the degree of their association with disease in groups of patients.

\begin{tabular}{|c|c|c|c|c|c|c|}
\hline Genotypes & Group & Control & $X^{2}$ & $\mathrm{P}$ & OR & $95 \% \mathrm{Cl}$ \\
\hline & $\begin{array}{c}1 \text { st } \\
\text { group }\end{array}$ & & & & & \\
\hline$C / C^{*} A / A^{\star} T / A$ & 0.488 & 0.103 & 18.86 & $<0.001$ & 8.086 & $3.025-21.65$ \\
\hline & $\begin{array}{c}2 \text { nd } \\
\text { group }\end{array}$ & & & & & \\
\hline$C / C^{*} A / A^{\star} T / A$ & 0.224 & 0.103 & 5.852 & $<0.05$ & 2.541 & $1.244-5.197$ \\
\hline$C / C^{*} G / A^{\star} T / A$ & 0.201 & 0.086 & 6.564 & $<0.01$ & 2.885 & $1.336-6.243$ \\
\hline$C / C^{\star} G / A^{\star} T / T$ & 0.025 & 0.111 & 4.434 & $<0.05$ & 0.203 & $0.052-0.886$ \\
\hline$C / C^{*} G / G^{*} T / T$ & 0.027 & 0.152 & 7.295 & $<0.01$ & 0.154 & $0.033-0.642$ \\
\hline & $\begin{array}{c}3 r d \\
\text { group }\end{array}$ & & & & & \\
\hline$C / T^{\star} A / A^{\star} T / A$ & 0.181 & 0.065 & 6.933 & $<0.01$ & 3.735 & $1.464-9.524$ \\
\hline$C / C^{*} G / G^{*} T / T$ & 0.042 & 0.152 & 3.884 & $<0.05$ & 0.223 & $0.051-0.965$ \\
\hline & $\begin{array}{c}4 \text { th } \\
\text { group }\end{array}$ & & & & & \\
\hline$T / T^{\star} A / A^{*} A / A$ & 0.075 & 0.001 & 6.483 & $<0.05$ & $\max$ & $\mathrm{N} / \mathrm{A}-\mathrm{max}$ \\
\hline
\end{tabular}

Notes: $x^{2}$ - Pearson's $x$-square criterion; $p$ - statistical significance; OR - odds ratio; $95 \% \mathrm{Cl}-95 \%$ credible interval for OR
In this regard, at the next stage, the character of the distribution (Fig. 1) and the connection (Table 2) of the genotype combinations with POAG in stratification by groups was determined.

Among the risk genotypes, association with the disease has been confirmed only for genotype combinations $C / C{ }^{*} A$ / $A^{*} T / A$. It was shown above that this genotype was found in the control group with a frequency $f=0.101$, and in POAG with frequency $f=0.238$, that is, 2.4 times more often $(p<0.001)$.

Henceforward, the nature of the connection between the genotype combinations with the disease when stratified by groups was calculated (Table 2).

In the 1st group, as in all patients with POAG, the association with the disease was determined only for genotype combinations $C / C{ }^{*} A / A^{*} T / A\left(X^{2}=18.86 ; p<0.001\right)$, which in 8, 1 times increased the chances of development POAG (OR = 8,086; 95\% Cl = 3,025-21,65).

In the 2nd group, the genotype combinations $C / C^{*} A / A^{*} T /$ $A\left(X^{2}=5.852, p<0.05\right)$ increased the chances of development POAG by 2.5 times $(\mathrm{OR}=2.541 ; 95 \% \mathrm{Cl}=1.244-5.197)$ as well as the genotype combinations $C / C^{\star} G / A^{*} T / A\left(X^{2}=6.564\right.$; $\mathrm{p}<0.01)$, which increased the chances by 2.9 times $(\mathrm{OR}=$ $2.885 ; 95 \% \mathrm{Cl}=1.336-6.243$ ).

Two other genotype combinations, which in the 2nd group had a statistically significant association with POAG, reduced the chances of its development: $C / C^{*} G / G^{*} T / T\left(X^{2}=\right.$ $7.295 ; p<0.01)$ in 6,7 times $(O R=0.154 ; 95 \% \mathrm{Cl}=0.033$ $0.642)$ and $C / C^{*} G / A^{*} T / T\left(x^{2}=4.434 ; p<0.05\right)-5.0$ times (OR $=0.203 ; 95 \% \mathrm{Cl}=0.052-0.886)$.

In the 3rd group, reasonable differences were found for the risk genotype combinations $C / T^{\star} A / A^{\star} T / A\left(X^{2}=6.933\right.$; $p<0.01)$, which increased the chances of development $P O A G$ by 3.7 times $(\mathrm{OR}=3.735 ; 95 \% \mathrm{Cl}=1.464-9.524)$ and for the protective genotype combinations $C / C^{*} \mathrm{G} / \mathrm{G}^{*} \mathrm{~T} / \mathrm{T}\left(\mathrm{X}^{2}=3.884\right.$; $\mathrm{p}<0.05)$, which reduced the chances of development POAG by 4,5 times $(\mathrm{OR}=0,223 ; 95 \% \mathrm{Cl}=0.051-0.965)$.

In the 4th group, the potentiating action of the combination of three mutant genotypes $T / T^{\star} A / A^{*} A / A\left(X^{2}=6.483 ; p<0.05\right)$ was shown, which increased the chances of development POAG.

\section{Discussion}

Although increased intraocular pressure (IOP) is a key risk factor for primary open-angle glaucoma, the fact that about one third of European-born patients with glaucoma have a normal intraocular pressure (normotensive glaucoma) suggests that other factors may also affect the propensity to degeneration of optic nerve $[9,20]$

There are increasing evidences of mitochondrial dysfunction in the susceptibility of the optic nerve to glaucoma $[1,5,12,14,19,23]$. The retinal ganglion cell axons don't have a myelin sheath, so that sufficient amount of adenosine triphosphate (ATP) to maintain the potency of action in the absence of myelin is provided by a sufficient number of mitochondria. The optic nerve is a site that is particularly 
susceptible to mitochondrial dysfunction [3, 13].

Genetic studies have shown that nuclear genes encoding mitochondrial proteins may contribute to the risk of COPD [10]. Recently, a large association of genomic studies revealed a significant association of POAG with single nucleotide polymorphism (SNPs) in the genomic region of TXNRD2, a nuclear-coded mitochondrial protein [1].

In previous studies, we determined the association of the rs35934224 polymorphism of the TXNRD2 gene with primary open-angle glaucoma. It was found that the polymorphism rs35934224 had differences in the distribution of genotypes and alleles between patients with POAG and control group. Moreover, the shift of alleles and genotypes toward minor causes increased severity of the pathological process. But the stratification of the perimeter changes in the POAG showed that the association with the disease was significant at stages III and IV. Moreover, the chances of development of the III stage of POAG were significantly higher in comparison with the I stage in carriers of $C / T$ and $T / T$ genotypes and allele $T$. In the same plan, the protective effect of the ancestral genotype $\mathrm{C} / \mathrm{C}$ was also strengthened [15].

FOXC1 is a gene that regulates the development of the anterior segment of the eye and is known to play a role in several autosomal dominant eye defects associated with increased risk of glaucoma, including the Axenfeld-Rieger anomaly, iris hypoplasia and Rieger syndrome [16, 18].

Foxc1 is expressed in the embryonic trabecular meshwork (TM) [25], the continuation of the expression of an abnormal gene product (from age-related, sub-clinical mutations) throughout life, or altered expression levels of FOXC1 may affect the normal function of the trabecular meshwork, thereby leading to an increased risk of glaucoma due to increased intraocular pressure This concept is confirmed by the fact that glaucoma associated with mutations in the genes of glaucoma development may occur at any time from birth to adulthood, and in some cases more than 70 years [24]. Moreover, in some patients with glaucoma due to FOXC1 mutations, the anomalies of the anterior segment can be very thin and easily passed through a clinical examination [11, 24], which is more consistent with POAG.

The connection of the polymorphism of the FOXC1 gene to the development of POAG has been studied in individual studies. Thus, in a study by British scientists [21] four polymorphisms were studied: rs2235715, rs2569889, rs2235716 and rs984253. In this case, all these polymorphisms do not cling to the coding region of the gene, and only the latter is located in the non-coding intron of the FOXC1 gene (16 13 294). We conducted a study of the association of polymorphisms rs984253 and rs2745599 of the FOXC1 gene with POAG. In which it was discovered that the distribution of genotypes and alleles had a relationship with POAG, but polymorphism rs984253 had no relation to its progression in the stages of the pathological process. While the polymorphism rs2745599 of the FOXC1 gene was related to the formation of the POAG of the most severe (IV) degree, and the risk of rapid progression of the disease was greater in the carriers of the minor allele $A$.

In this study, we determined the effects of the combinations of genotypes of polymorphisms on the development of POAG and the degree of their association with the disease. We found that the association with the disease had the genotype $C / T^{\star} A / A^{\star} T / A$ as a comparison of control with all patients, and with stratification - from the 1st, 2nd and 3rd groups of patients. In our opinion, this convincingly indicated the evidentiary effect of this combination of genotypes and on the occurrence of POAG, and on its progression in the stages of perimetric changes. The risk of occurrence of POAGs in carriers of $C / T^{\star} A / A^{\star} T / A$ genotypes was increased by 2.8 times $(p<0.001)$. Interestingly, in this combination, the two polymorphisms had heterozygous genotypes (rs35934224 - C/T, rs984253 - $T / A)$, and the genotype rs2745599 was a mutant homozygote $A / A$.

A combination of $C / C^{*} G / A^{*} T / A$ genotypes was also important for the progression of the disease to stage II, which increased the risk of developing the II stage of POAG by 2.9 times $(p<0.01)$ compared to control.

The risk of both general POAG and stage IV development increased the presence of combinations of three minor $T / T^{\star} A / A^{*} A / A$ genotypes that were found only in patients with POAG (at stage $\| \mathrm{f}=0.025$, in stage $\mathrm{III}-\mathrm{f}=$ 0.036 , and for IV- $f=0.071$ ). In our opinion, this testified in favor of the proposed working hypothesis of the study and confirmed that the more combined the genotypes of the mutant alleles, the stronger this genotype affects the development of POAG.

\section{Conclusions}

1. The association with the disease had the genotype $C / T^{\star} A / A^{*} T / A$ as a comparison of control with all patients, and with stratification - with the 1st, 2nd and 3rd groups of patients. The risk of the occurrence of POAG in carriers of $C / T^{\star} A / A^{*} T / A$ genotypes was increased by 2.8 times (OR = 2.775; $95 \% \mathrm{Cl}=1.532-5.021)$. Also, the combination of minor $T / T^{\star} A / A^{\star} A / A$ genotypes made a significant increase in the risk of development of POAG $(p<0.05)$, since no such genotype was detected in the control group.

2. For the progression of the disease to the II stage, the combination of $C / C^{*} G / A^{*} T / A$ genotypes was also important, which increased the risk of development of the II stage of POAG in 2.9 times $(p<0.01)$ as compared with the control.

3 . The probable protective effect on the POAG was determined to combine the genotypes $C / C^{*} G / G * T / T$, which reduced the chances of development of the POAG by 7.7 times $(\mathrm{OR}=0.132 ; 95 \% \mathrm{Cl}=0.044-0.383)$. The combination of genotypes $\mathrm{C} / \mathrm{T}^{\star} \mathrm{G} / \mathrm{A}^{*} \mathrm{~T} / \mathrm{T}$ reduced the chances by 6.7 times $(\mathrm{OR}=0.157 ; 95 \% \mathrm{Cl}=0.035-0.697)$ and the combination of genotypes $C / C^{*} A / A^{*} T / T$ and $C / C * G / A * T / T-3.8$ times for both cases $(\mathrm{OR}=0.263 ; 95 \% \mathrm{Cl}=0.101-0.685)$. 


\section{References}

[1] Bailey, J. N., Loomis, S. J., Kang, J. H., Allingham, R. R., Gharahkhani, P., Khor, C. C., ... Wiggs, J. L. (2016). Genomewide association analysis identifies TXNRD2, ATXN2 and FOXC1 as susceptibility loci for primary open angle glaucoma. Nat. Genet., 48(2), 189-194. doi: 10.1038/ng.3482

[2] Caprioli J, Munemasa, Y., Kwong, J. M., \& Piri, N. (2009). Overexpression of thioredoxins 1 and 2 increases retinal ganglion cell survival after pharmacologically induced oxidative stress, optic nerve transection, and in experimental glaucoma. Trans. Am. Ophthalmol. Soc., 107, 161-165. PMID: 20126492

[3] Carelli, V., Ross-Cisneros, F. N., \& Sadun, A. A. (2004). Mitochondrial dysfunction as a cause of optic neuropathies. Prog. Retin. Eye. Res., 23(1), 53-89. doi: /10.1016/ j.preteyeres.2003.10.003

[4] Chen, Y., Cai, J., \& Jones, D. P. (2006). Mitochondrial thioredoxin in regulation of oxidant-induced cell death. FEBS Lett, 580(2829), 6596-6602. doi: 10.1016/j.febslet.2006.11.007

[5] Chrysostomou, V., Rezania, F., Trounce, I. A., \& Crowston, J. G. (2013). Oxidative stress and mitochondrial dysfunction in glaucoma. Curr. Opin. Pharmacol., 13(2), 12-15. doi: org/ 10.1016/j.exer.2010.07.015

[6] Cook, C. (2009). Glaucoma in Africa: size of the problem and possible solutions. J. Glaucoma, 18(2), 124-128. doi: 10.1097/ IJG.0b013e318189158c

[7] Gong, G., Kosoko-Lasaki, S., Haynatzki, G., Lynch, H. T., Lynch, J. A., \& Wilson, M. R. (2007). Inherited, familial and sporadic primary open-angle glaucoma. J. Natl. Med. Assoc., 99(5), 559-563. PMID: 17534014

[8] Gong, G., Kosoko-Lasaki, O., Haynatzki, G. R., \& Wilson, M. R. (2004). Genetic dissection of myocilin glaucoma. Hum. Mol. Genet., 13(1), R91-R102. doi: 10.1093/hmg/ddh074

[9] Hysi, P. G., Cheng, C. Y., Springelkamp, H., Macgregor, S., Bailey, J. N., Wojciechowski, R., ... Aung, T. (2014). Genomewide analysis of multi-ancestry cohorts identifies new loci influencing intraocular pressure and susceptibility to glaucoma. Nat. Genet., 46(10), 1126-1130. doi: 10.1038/ng.3087

[10] Lascaratos, G., Garway-Heath, D. F., Willoughby, C. E., Chau, K. Y., \& Schapira, A. H. (2012). Mitochondrial dysfunction in glaucoma: understanding genetic influences. Mitochondrion. 12(2), 202-212. doi: org/10.1016/j.mito.2011.11.004

[11] Lehmann, O. J., Tuft, S., Brice, G., Smith, R., Blixt, A., Bell, R. ... Bhattacharya, S. S. (2003). Novel anterior segment phenotypes resulting from forkhead gene alterations: evidence for cross-species conservation of function. Invest. Ophthalmol. Vis. Sci., 44(6), 2627-2633. doi: 10.1167/iovs.020609

[12] Lee, S., Van Bergen, N. J., \& Kong, G. Y. (2011). Mitochondrial dysfunction in glaucoma and emerging bioenergetic therapies. Exp. Eye. Res., 93(2), 204-212. doi: org/10.1016/ j.exer.2010.07.015

[13] Lin, M. T., \& Beal, M. F. (2006). Mitochondrial dysfunction and oxidative stress in neurodegenerative diseases. Nature, 443 , 787-795. doi: 10.1038/nature05292

[14] Lu, T., Zullo, J., \& Aron, L. (2014). REST and stress resistance in ageing and Alzheimer's disease. Nature, 507, 448-454. doi:
$10.1038 /$ nature 13163

[15] Malachkova N. V., \& Veretelnyk S. P. (2018). Correlation of rs35934224 polymorphism of TXNRD2 gene with primary openangle glaucoma. Archive of Ukrainian ophthalmology, 6(3), 21-25.

[16] Mirzayans, F., Gould, D. B., H?on, E., Billingsley, G. D., Cheung, J. C., Mears, A. J., \& Walter, M. A. (2000). Axenfeld-Rieger syndrome resulting from mutation of the FKHL7 gene on chromosome 6p25. Eur. J. Hum. Genet., 8(1), 71-74. doi: 10.1038/sj.ejhg.5200354

[17] Nesterov, A. P. (2008). Glaucoma. M.: OOO "Medical information agency".

[18] Nishimura, D. Y., Swiderski, R. E., Alward, W. L., Searby, C. C., Patil, S. R., Bennet, S. R., ... Sheffield, V. C. (1998). The forkhead transcription factor gene FKHL7 is responsible for glaucoma phenotypes which map to 6p25. Nat. Genet., 19(2), 140-147. doi: 10.1038/493

[19] Osborne, N. N., \& del Olmo-Aguado, S. (2013). Maintenance of retinal ganglion cell mitochondrial functions as a neuroprotective strategy in glaucoma. Curr. Opin. Pharmacol., 13(1), 16-22. doi: 10.1016/j.coph.2012.09.002

[20] Ozel, A. B., Moroi, S. E., Reed, D. M., Nika, M., Schmidt, C. M., Akbari, S., ... Li, J. Z. (2014) Genome-wide association study and meta-analysis of intraocular pressure. Hum. Genet., 133(1), 41-57. doi: 10.1007/s00439-013-1349-5

[21] Park, S., Jamshidi, Ya., Vaideanu, D., Fraser, S., \& Sowden, J. C. (2012). Common TGFB2, BMP4, and FOXC1 variants are not associated with primary open-angle glaucoma. Mol. Vis., 18, 1526-1539. PMID: 22736943

[22] Quigley, H. A., \& Broman, A.T. (2006). The number of people with glaucoma worldwide in 2010 and $2020 \mathrm{Br}$. J. Ophthalmol., 90(3), 262-267. doi: 10.1136/bjo.2005.081224

[23] Serdyuk, V. M. (2015). Clinical and experimental substantiation of neuroprotection in the complex treatment of patients with primary open-angle glaucoma (Doctoral dissertation). http://www.irbis-nbuv.gov.ua/

[24] Shields, M. B. (1983). Axenfeld-Rieger syndrome: a theory of mechanism and distinctions from the iridocorneal endothelial syndrome. Trans. Am. Ophthalmol. Soc., 81, 736-784.

[25] Smith, R. S., Zabaleta, A., Kume, T., Savinova, O. V., Kidson, S. H., Martin, J. E., ... John, S. W. (2000). Haploinsufficiency of the transcription factors FOXC1 and FOXC2 results in aberrant ocular development. Hum. Mol. Genet., 9(7), 1021-1032.

[26] van der Merwe, E. L., \& Kidson, S. H. (2016). Wholemount imaging reveals abnormalities of the aqueous outflow pathway and corneal vascularity in Foxc1 and Bmp4 heterozygous mice. Exp. Eye. Res., 146, 293-303. doi: 10.1016/ j.exer.2016.04.003

[27] Vitovs'ka, O. P., \& Rykov, S. O. (2012). Organization of ophthalmologycal care for patients with glaucoma and its normative-legal support. Modern medical technology, 2, 4650.

[28] Wiggs, J. L., \& Pasquale, L. R. (2017). Genetics of glaucoma. Hum. Mol. Genet., 26(R1), R21-R27. doi: 10.1093/hmg/ddx184

\section{ВПЛИВ СПОЛУЧЕНЬ ГЕНОТИПІВ ПОЛІМОРФІЗМІВ RS35934224 ГЕНА TXNRD2, RS2745599 I RS984253 ГEHA FOXC1 HA РОЗВИТОК ПЕРВИННОЇ ВІДКРИТОКУТОВОЇ ГЛАУКОМИ І СТУПІНЬ ЇХ АСОЦІАЦІЇ З ЗАХВОРЮВАННЯМ Малачкова Н. В., Веретельник С. П., Слободян П. П.}

Первинна відкритокутова глаукома (ПВКГ) - це складне захворювання, викликане численними генетичними й екологічними фракторами, а також їх взаємодією. У останніх наукових дослідженнях було доведено вплив сполучень поліморфних генотипів та нерівноважне зчеплення алелей генів, що мають відношення до розвитку ПВКГ. Мета дослідження - визначення впливу 
сполучень генотипів поліморфізмів rs35934224 гена TXNRD2, rs2745599 і rs984253 гена FOХC1 на розвиток ПВКГ і ступінь їх асоціації з захворюванням. Проведено дослідження 93 хворих (185 очей) з ПВКГ I-IV стадій та 89 добровольців (178 очей), у яких не було встановлено будь-якої глаукоми, що склали контрольну групу. Хворих було розподілено на 4 групи відповідно до ступеня периметричних змін (Nesterov A. P., 2008). Всім хворим виконано візометрію, комп'ютерну периметрію, тонометрію, біомікроскопію, офтальмоскопію, гоніоскопію, кератопахіметрію, оптичну когерентну томографію зорового нерва. Аналіз поліморфізмів rs35934224 гена TXNRD2, rs2745599 і rs984253 гена FOXC1 проведено методом полімеразної ланцюгової реакції у реальному часі в автоматичному ампліфікаторі Gene Amp® PCR System 7500 (Applied Biosystems, CШA). Ha першому етапі дослідження проводили виділення геномної ДНК з цільної венозної крові з використанням стандартних реактивів PureLink $\Theta$ Genomic DNA Kit For purification of genomic DNA, виробник INVITROGEN (США). Аналіз поліморфрiзму здійснено з використанням уніфрікованих тест-систем TaqMan Mutation Detection Assays Life-Technology (СШA). Встановлено, що асоціацію з ПВКГ мав генотип $C / T^{\star} A / A^{\star} T / A$ як при порівнянні контролю зі всіма хворими, так і при стратифрікації - $з$ 1-ю, 2-ю і 3-ю групами хворих. Отримані результати свідчать про доказовий вплив цього сполучення генотипів і на виникнення ПВКГ, і на її прогресування за стадіями периметричних змін. Ризик виникнення ПВКГ у носії сполучення генотипів $C / T^{\star} A / A^{*} T /$ А збільшено у 2,8 рази ( $<<0,001)$. У цьому сполученні два поліморфрізми мали гетерозиготні генотипи (rs35934224 - C/T, rs984253 - T/A), а генотип rs2745599 - мутантну гомозиготу A/A. Для прогресування захворювання до II стадії мало значення також сполучення генотипів $C / C^{*} G / A^{*} T / A$, яке збільшує ризик розвитку II стадії ПВКГ у 2,9 рази $(p<0,01)$ у порівнянні $з$ контролем. Ризик як загалом ПВКГ, так і розвитку IV стадії підвищувала наявність сполучень трьох мінорних генотипів $T$ / $T^{\star} A / A^{\star} A / A$, яке зустрічалося тільки у хворих на ПВКГ (при II стадії $f=0,025$, при III стадії - $f=0,036$, а при IV - $f=0,071$ ). На наш погляд, це свідчило на користь висунутої робочої гіпотези дослідження та підтвердило, що чим більше у сполученні генотипів мутантних алелей, тим сильніше такий генотип впливає на розвиток ПВКГ.

Ключові слова: первинна відкритокутова глаукома, хромосома, генотип, поліморфізм, ген TXNRD2, ген FOXC1, алель, гетерозигота.

\section{ВЛИЯНИЕ СОЕДИНЕНИЙ ГЕНОТИПОВ ПОЛИМОРФИЗМОВ RS35934224 ГЕНА TXNRD2, RS2745599 И RS984253 ГЕНА FОХC1 НА РАЗВИТИЕ ПЕРВИЧНОЙ ОТКРЫТОУГОЛЬНОЙ ГЛАУКОМЫ И СТЕПЕНЬ ИХ АССОЦИАЦИИ С ЗАБОЛЕВАНИЕМ Малачкова Н. В., Веретельник С. П., Слободян П. П.}

Первичная открытоугольная глаукома (ПОУГ) - это сложное заболевание, вызванное многочисленными генетическими и экологическими фракторами, а также их взаимодействием. В последних научных исследованиях было доказано влияние соединений полиморфных генотипов и неравновесное сцепление аллелей генов, имеющих отношение к развитию ПОУГ. Цель исследования - определение влияния соединений генотипов полиморфизмов rs35934224 гена TXNRD2, rs2745599 и rs984253 гена FOXC1 на развитие ПОУГ и степень их ассоциации с заболеванием. Проведено исследование 93 больных (185 глаз) с ПОУГ I-IV стадий и 89 добровольцев (178 глаз), у которых не было установлено какой-либо глаукомы, составивиих контрольную группу. Больные были разделены на 4 группы согласно степени периметрических изменений (Nesterov A. P., 2008). Всем больным выполнена визометрия, компьютерная периметрая, тонометрия, биомикроскопия, офтальмоскопия, гониоскопия, кератопахиметрия, оптическая когерентная томография зрительного нерва. Анализ полиморфизмов rs35934224 гена TXNRD2, rs2745599 и rs984253 гена FOХC1 проведено методом полимеразной цепной реакции в реальном времени в автоматическом амплифрикаторе Gene Amp® PCR System 7500 (Applied Biosystems, CШA). Ha первом этапе исследования проводили выделение геномной ДНК из иельной венозной крови с использованием стандартных реактивов PureLink® Genomic DNA Kit For purification of genomic DNA, производитель INVITROGEN (CWA). Анализ полиморфизма осуществлено с использованием унифицированных тесm-сuстем TaqMan Mutation Detection Assays Life-Technology (CШA). Установлено, что ассоциации с ПОУГ имел генотип $C / T^{\star} A / A^{*} T / A$ как при сравнении контроля со всеми больными, так и при стратифрикации - с 1-й, 2-й и 3-й группами больных. Полученные результаты свидетельствуют о доказательном влияние этого соединения генотипов и на возникновение ПОУГ, и на ее прогрессирование по стадиям периметрических изменений. Риск возникновения ПОУГ у носителей соединений генотипов $C / T^{\star} A / A^{\star} T / A$ увеличено в 2,8 раза (p <0,001). В этом сочетании два полиморфизма имели гетерозиготные генотипы (rs35934224 - C / T, rs984253 - T/A), а генотип rs2745599 - мутантную гомозиготу A/A. Для прогрессирования заболевания до II стадии имело значение также соединение генотипов C/C*G/A*T/A, которое увеличивает риск развития II стадии ПОУГ в 2,9 раз ( $p<0,01)$ по сравнению с контролем. Риск как в целом ПОУГ, так и развития IV стадии повышало наличие соединение трех минорных генотипов $T / T^{\star} A / A{ }^{*} A / A$, которое встречалось только у больных ПОУГ (при II стадии $f=0,025$, при III стадии - $f=0,036$, а при IV - $f=0,071$ ). На наш взгляд, это свидетельствовало в пользу выдвинутой рабочей гипотезы исследования и подтвердило, что чем больше в соединении генотипов мутантных аллелей, тем сильнее такой генотип влияет на развитие ПОУГ.

Ключевые слова: первичная открытоугольная глаукома, хромосома, генотип, полиморфизм, ген TXNRD2, ген FOXC1, аллель, гетерозигота. 